\title{
Adjuvant Therapy of Uveal Melanoma: Current Status
}

\author{
Pierre L. Triozzi ${ }^{a} \quad$ Arun D. Singh ${ }^{b}$ \\ ${ }^{a}$ Comprehensive Cancer Center of Wake Forest University, Winston-Salem, N.C., and \\ ${ }^{b}$ Department of Ophthalmic Oncology, Cole Eye Institute, Cleveland Clinic, Cleveland, Ohio, USA
}

\section{Key Words}

Melanoma · Metastasis · Adjuvant therapy

\begin{abstract}
The survival of patients with uveal melanoma remains poor because of the development of metastatic disease. Adjuvant therapy after treatment of the primary tumor has been tested but has not been shown to prevent the development of metastasis. Several new approaches are being developed. Cytotoxic and immunotherapeutic regimens are being more rationally applied using tumor genetic criteria to better identify patients at risk. Trials in the adjuvant setting of novel immunotherapeutic and targeted agents active in the metastatic setting are being developed, as are approaches to promote cellular differentiation and dormancy. The rarity and biology of uveal melanoma present challenges. Participation in well-designed, scientifically sound clinical trials is critical.

(C) 2014 S. Karger AG, Basel
\end{abstract}

\section{Introduction}

Despite advances in diagnosis and the treatment of the primary tumor, the overall mortality rate of uveal melanoma remains high because of the development of metastatic disease, predominantly in the liver. Considerable progress has been made in identifying patients at risk for metastatic death. That the loss of a chromosome 3 in the primary tumor is associated with the development of metastasis is well established, and a variety of techniques are being used clinically to test tumors for monosomy 3 and other high-risk chromosomal alterations [1]. Gene array technology is also being applied to tumors to classify tumor gene expression as 'class 1', associated with a low risk of metastasis, and 'class 2 ', associated with a high risk [2]. 
Ocular Oncology

and Pathology

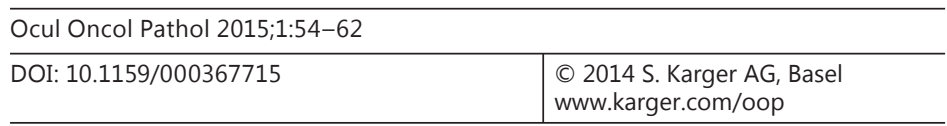

Triozzi and Singh: Adjuvant Therapy of Uveal Melanoma: Current Status

Treatment of the primary tumor in uveal melanoma is highly effective; local recurrences are rare, i.e. $<5 \%$. The development of metastasis, which is often observed more than 5 years after the treatment of the primary tumor, is frequent, occurring in up to $50 \%$, indicating that these patients harbored subclinical micrometastases at presentation [3]. Moreover, tumor cells are detected in the blood of many patients clinically free of metastasis, including at diagnosis [4]. Metastatic uveal melanoma is almost invariably refractory to therapy. Systemic therapy rarely produces durable responses, and there is no evidence that current treatments actually prolong survival. Systemic therapy may be more active in the adjuvant setting, in treating microscopic rather than macroscopic metastatic tumor, where multiple mechanisms of resistance can complicate.

\section{Published Studies}

\section{Randomized Trials}

Only two randomized systemic adjuvant therapy trials have been reported in patients with uveal melanoma, both now more than a decade ago. The largest involved 348 patients and tested dacarbazine, still the only cytotoxic chemotherapeutic approved to treat melanoma [5]. A randomized study of the immune modulator methanol extraction residue of bacille Calmette-Guérin (BCG) has also been reported [6]. Differences in survival were not observed between the adjuvant-treated and the untreated control group in either study (table 1). Although these studies were randomized, they did not apply the now better-established clinical and cytohistologic prognostic factors, and the number of patients in the treatment and observation groups actually at risk for metastasis is not known. Statistical power cannot be adequately calculated, but sample sizes in these trials were most likely inadequate. Furthermore, adjuvant dacarbazine and adjuvant BCG have not been shown to improve survival in high-risk cutaneous melanoma.

\section{Nonrandomized Trials}

Systemic adjuvant interferon (IFN) has been shown to improve recurrence-free survival in high-risk cutaneous melanoma. Effects on overall survival are less clear. Two studies with historical controls matched for clinical prognostic factors did not show any benefit of systemic adjuvant low-dose IFN. Studies with historical controls matched for clinical prognostic factors also did not show any benefit for intra-arterial hepatic fotemustine, a cytotoxic agent (table 2) [7-9]. These nonrandomized studies predated the introduction of molecular prognostication, and the number of patients in the treatment and control groups actually at risk for metastasis is not known. Also, 2 years of adjuvant low-dose IFN have not been shown to improve survival in high-risk cutaneous melanoma. In patients with cutaneous melanoma, higher dosing or more protracted dosing, namely up to 5 years, of low-dose IFN is standard.

\section{Current Approaches}

Several approaches are now being implemented to improve adjuvant therapy for uveal melanoma. Most importantly, existing cytotoxic and immunotherapeutic regimens are being more rationally applied using tumor genetic criteria to better identify patients at risk. The treatment of advanced cutaneous melanoma has been revolutionized with the development 
Table 1. Uveal melanoma adjuvant therapy: randomized trials

\begin{tabular}{|c|c|c|c|c|}
\hline Treatment & $\mathrm{n}$ & Treatment eligibility & Result & Reference \\
\hline $\begin{array}{l}\text { BCG i.d. weekly, } 4 \text { times; then } \\
\text { monthly for } 11 \text { months }\end{array}$ & 113 & $\begin{array}{l}\text { posterior uveal } \\
\text { melanoma }\end{array}$ & $\begin{array}{l}\text { no difference in survival rate of treated } \\
(59 \%, n=34) \text { vs. observation }(70 \% \text {, } \\
n=79) ; p=0.60\end{array}$ & $\begin{array}{l}\text { McLean et al. [6], } \\
1990\end{array}$ \\
\hline $\begin{array}{l}\text { Dacarbazine } 200 \mathrm{mg} / \mathrm{m}^{2} \text { i.v. } \\
\text { daily for } 5 \text { days every } 4 \text { weeks, } \\
6 \text { times }\end{array}$ & 348 & $\begin{array}{l}>10 \mathrm{~mm} \text { LTD, > } 5 \mathrm{~mm} \\
\text { tumor height }\end{array}$ & $\begin{array}{l}\text { no difference in 5-year survival rate of } \\
\text { treated }(71 \%) \text { vs. observation }(68 \%) ; \\
\text { p = not significant }\end{array}$ & $\begin{array}{l}\text { Desjardins et al. } \\
{[5], 1998}\end{array}$ \\
\hline
\end{tabular}

i.d. = Intradermally; i.v. = intravenously; LTD = largest tumor diameter.

Table 2. Uveal melanoma adjuvant therapy: nonrandomized trials

\begin{tabular}{|c|c|c|c|c|c|}
\hline Treatment & $\mathrm{n}$ & Treatment eligibility & Historic controls & Result & Reference \\
\hline $\begin{array}{l}\text { Interferon alfa- } 2 b \\
3 \text { million units s.c., } \\
3 \text { times per week for } \\
1 \text { year }\end{array}$ & 39 & $\begin{array}{l}\text { no evidence of metastasis, } \\
<2 \text { months from primary } \\
\text { therapy }\end{array}$ & $\begin{array}{l}72 \text { patients matched for } \\
\text { sex, tumor localization, } \\
\text { LTD, and tumor height }\end{array}$ & $\begin{array}{l}\text { no difference in } 3 \text {-year } \\
\text { survival rate of treated } \\
(82 \%) \text { vs. historic controls } \\
(90 \%) ; p=0.27\end{array}$ & $\begin{array}{l}\text { Richtig et al. } \\
{[7], 2006}\end{array}$ \\
\hline $\begin{array}{l}\text { Interferon alfa-2a } \\
3 \text { million units s.c., } \\
3 \text { times per week for } \\
2 \text { years }\end{array}$ & 121 & $\begin{array}{l}\text { age } \geq 65 \text { years, } \mathrm{LTD} \geq 15 \\
\mathrm{~mm} \text {, ciliary body } \\
\text { involvement, extrascleral } \\
\text { extension }\end{array}$ & $\begin{array}{l}242 \text { patients matched } \\
\text { for age ( } \pm 5 \text { years), LTD } \\
( \pm 3 \mathrm{~mm}) \text {, gender, and } \\
\text { time between primary } \\
\text { therapy and treatment } \\
\text { initiation }\end{array}$ & $\begin{array}{l}\text { no difference in 5-year } \\
\text { survival rate of treated } \\
(76 \%) \text { vs. historic controls } \\
(83 \%) ; p=0.91\end{array}$ & $\begin{array}{l}\text { Lane et al. } \\
{[8], 2009}\end{array}$ \\
\hline $\begin{array}{l}\text { Fotemustine } 100 \mathrm{mg} / \\
\mathrm{m}^{2} \text { i.a.h. weekly for } \\
4 \text { weeks; then every } \\
3 \text { weeks, } 5 \text { times }\end{array}$ & 22 & $\begin{array}{l}\text { choroidal involvement, } \\
\text { LTD > } 20 \mathrm{~mm} \text {, extrascleral } \\
\text { extension, tumor height } \\
\text { >15 mm }\end{array}$ & $\begin{array}{l}66 \text { patients matched for } \\
\text { clinical and tumor } \\
\text { characteristics }\end{array}$ & $\begin{array}{l}\text { no difference in 5-year } \\
\text { survival rate of treated } \\
(75 \%) \text { vs. historic controls } \\
(56 \%) ; p=0.5\end{array}$ & $\begin{array}{l}\text { Voelter et al. } \\
\text { [9], } 2008\end{array}$ \\
\hline
\end{tabular}

s.c. = Subcutaneously; i.a.h. = intra-arterial hepatic; LTD = largest tumor diameter.

of the cytotoxic T lymphocyte antigen (CTLA)-4 inhibitor, ipilimumab [10], and this and other immunotherapeutic approaches are under investigation. The treatment of advanced cutaneous melanoma has also been revolutionized with the development of targeted agents that inhibit mutated $B R A F$. Although mutations in BRAF are rare in uveal melanoma, mutations of other members of the mitogen-activated protein kinase (MAPK) cell signaling pathway, namely GNAQ, are common and are being targeted [11]. Epigenetic events mediated by DNA methylation and histone modification, which do not affect DNA sequence but which nevertheless lead to the changes in gene expression that promote the abnormal cellular differentiation that characterizes cancer, are also being addressed pharmacologically. A review of the agents being tested clinically and of those being developed for testing follows (table 3). 
Table 3. Uveal melanoma adjuvant therapy: current trials ${ }^{1}$

\begin{tabular}{|c|c|c|c|}
\hline Treatment & Status & Results & $\begin{array}{l}\text { ClinicalTrials.gov } \\
\text { identifier }^{2}\end{array}$ \\
\hline Sunitinib or valproic acid & not yet recruiting & - & NCT02068586 \\
\hline $\begin{array}{l}\text { mRNA (encoding gp } 100 \text { and tyrosinase)-transfected } \\
\text { dendritic cell vaccination }\end{array}$ & recruiting & no results available & NCT00929019 \\
\hline Dacarbazine and interferon alfa- $2 b$ & active, not recruiting & no results available & NCT01100528 \\
\hline Autologous tumor RNA dendritic cell vaccination & not yet recruiting & - & NCT01983748 \\
\hline
\end{tabular}

\section{Cytotoxic Chemotherapeutics}

\section{Fotemustine}

Like dacarbazine, fotemustine is an alkylating agent with activity in melanoma. The response rate in patients with metastatic melanoma was higher with fotemustine than dacarbazine in a randomized trial [12]. Fotemustine has been investigated both as an intra-arterial hepatic and an intravenous chemotherapeutic in patients with uveal melanoma $[13,14]$. Data from a phase III trial that compared intra-arterial hepatic with intravenous administration in patients with uveal melanoma liver metastases have been presented. Even though intraarterial hepatic fotemustine administration led to a higher overall response rate and longer progression-free survival compared with intravenous administration, it did not lead to an improvement in the overall survival [15]. A randomized trial testing adjuvant intravenous fotemustine is currently ongoing, selecting only high-risk patients [16]. The primary objective is to determine effects on disease-free survival.

\section{Cisplatin, Sunitinib, and Tamoxifen}

Platinum compounds, which cross-link DNA, are considered to be among the more active cytotoxic chemotherapeutics in melanoma [17]. Sunitinib inhibits receptor tyrosine kinases, which signal through several pathways, including the MAPK pathway. It has antiangiogenic and antiproliferative effects and has demonstrated activity in patients with metastatic uveal melanoma in a pilot study [18]. There is evidence that the antiestrogen tamoxifen can inhibit the ability of uveal melanoma cells to metastasize [19]. Additive/synergistic antitumor interactions between tamoxifen and cisplatin and between sunitinib and cisplatin have been observed [20,21]. A pilot trial of adjuvant therapy with cisplatin, sunitinib, and tamoxifen has been activated in patients with high-risk uveal melanoma who have undergone primary therapy [22]. The objectives are to determine the effect on disease-free and overall survivals as well as the toxicity of this regimen.

\section{Immunotherapy}

\section{Interferon Alfa-2b and Dacarbazine}

Patients with high-risk tumor genotypes have been enrolled on adjuvant therapy with a sequential program of low-dose dacarbazine and interferon alfa- $2 \mathrm{~b}$, a regimen that increased 
disease-free survival in cutaneous melanoma patients in a randomized adjuvant trial [23]. The goals are to estimate disease-free survival of this patient population to establish a baseline to help design follow-up clinical trials and to establish a patient cohort for biologic studies. Specifically, the treatment was applied as a means of 'unmasking' key immune factors. Both drugs regulate antitumor immune responses. Interferon alfa- $2 b$, a cytokine with a broad spectrum of immunomodulatory activities, has been shown to prevent metastasis in a mouse ocular melanoma model [24]. Dacarbazine can sensitize tumors to immune effectors, directly activating immune effectors, releasing antigenic determinants and cross-priming and/or reducing regulatory $T$ cells [25]. Natural killer cell activity is increased in patients treated with the combination [26]. Furthermore, the sequential nature of the program selected allows assessing the effects of a chemical and a cytokine independently. Accrual has been completed, and results will be forthcoming.

\section{Ipilimumab}

CTLA-4 is a negative regulator of T cell responses, an immune 'checkpoint'. The monoclonal antibody ipilimumab blocks CTLA-4, which in turn augments T cell responses to tumor cells. In phase III trials in patients with advanced cutaneous melanoma, ipilimumab improved overall survival when administered alone and compared to gp100 vaccine (10.1 vs. 6.5 months), and when combined with dacarbazine and compared to dacarbazine alone (11.2 vs. 9.1 months). Although response rates in these trials were low $(5.7-10.9 \%$ for ipilimumab in previously treated patients and $15.2 \%$ in combination with dacarbazine in treatment-naïve patients), responses in several patients had been durable [27, 28]. However, toxicity can be problematic. Severe immune-mediated adverse events including colitis/diarrhea, dermatitis, hepatitis, and endocrinopathies, likely the result of breaking immune tolerance upon CTLA-4 blockade, have been observed in $18.4 \%$ of the patients [29]. Uveitis can also occur. The antitumor effects of ipilimumab in metastatic uveal melanoma have not been defined. Response rates in retrospective analyses have been approximately 5\%, and overall survivals have ranged from 5.2 to 9.6 months [30-32]. Between 28 and $45 \%$ of patients with uveal melanoma did not complete the recommended four infusions because of disease progression or toxicity. The effects of ipilimumab in the adjuvant setting are currently being evaluated in cutaneous melanoma. Adjuvant ipilimumab has recently been reported to improve recurrence-free survival in stage III cutaneous melanoma [33]. Effects on overall survival are not yet known. Toxicity was problematic. Approximately $50 \%$ of the patients who started adjuvant ipilimumab discontinued their therapy due to treatment-related adverse effects. A phase I/II trial of adjuvant ipilimumab in patients with uveal melanoma whose tumors manifested high-risk genotypes was initiated but has been suspended [34].

\section{Dendritic Cell Vaccine}

Vaccines have been an attractive though not yet clinically approved adjuvant therapy for melanoma. Dendritic cell vaccines have shown promise [35]. An open-label nonrandomized phase II intervention study of a vaccine approach consisting of autologous dendritic cells transfected with melanoma antigens has been initiated in HLA-A2-positive patients with high-risk uveal melanoma with proven expression of tyrosinase and/or gp100 [36]. This is an exploratory study aiming to demonstrate proof of principle. The first study endpoints are in vivo immunological response induced in high-risk uveal melanoma patients vaccinated with mRNA-transfected dendritic cells, administered intravenously or intradermally, and toxicity. Secondary study endpoints are progression-free survival, overall survival, and toxicity. 


\section{Ocular Oncology \\ and Pathology}

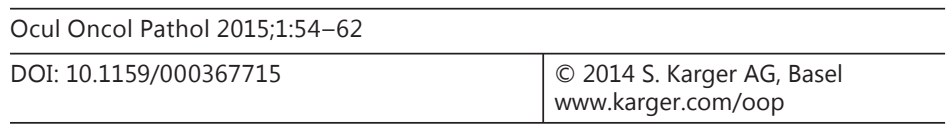

Triozzi and Singh: Adjuvant Therapy of Uveal Melanoma: Current Status

\section{MAPK Inhibitors}

Randomized trials have led to the approval of three oral agents to treat patients with metastatic melanoma manifesting mutations in $B R A F$, which occur in about half of all patients with cutaneous melanoma. When compared to dacarbazine, the BRAF inhibitors, vemurafenib and dabrafenib, significantly prolonged overall and/or progression-free survivals and increased response rate $[37,38]$. Clinically significant cutaneous side effects are common with both vemurafenib and dabrafenib. Secondary cancers, including cutaneous squamous cell carcinoma and second melanomas, have also been observed. MEK is 'downstream' to BRAF in the MAPK pathway. Trametinib, a MEK inhibitor, increased progression-free survival in cutaneous melanoma patients with tumor BRAF mutations when compared with chemotherapy (dacarbazine or paclitaxel) [39]. Secondary cancers have been less frequently observed with MEK inhibitors. The combination of dabrafenib with trametinib, which significantly increases response rate when compared to monotherapy, has also been approved for use in cutaneous melanoma patients with tumor BRAF mutations [40]. Activation of the MAPK pathway by mutant $G N A Q$, which acts 'upstream' to BRAF, appears to be critical for the development of uveal melanoma [41]. The MEK inhibitor selumetinib, which did not improve overall survival in trials in patients with cutaneous melanoma [42], was tested in a phase II study in patients with advanced uveal melanoma, most with tumor GNAQ mutations [43]. Treatment with selumetinib increased progression-free survival (15.9 vs. 7 weeks) and response rate (15 vs. $0 \%$ ) when compared to treatment with temozolomide, essentially an oral formulation of dacarbazine. The difference in overall survival was not reported to be significant. Additional trials of MEK inhibitors in metastatic uveal melanoma are underway. As noted, sunitinib can inhibit signaling through the MAPK pathway through effects primarily upstream of GNAQ. Its use as a single agent in the adjuvant setting is under investigation [44].

The major limitation of MAPK pathway inhibitors in the treatment of melanoma has been the lack of durable response; these drugs tend to work for an average of 6-10 months. It is possible that adjuvant therapy with MAPK pathway inhibitors leads to more aggressive recurrence that will confound overall survival. Furthermore, toxicity in the adjuvant setting again may be problematic. Long-term toxicities have not been identified.

\section{Epigenetic Modifiers}

\section{Histone Deacetylase Inhibitors}

DNA is wrapped around histones, and DNA expression is regulated by histone acetylation and deacetylation. Thus, inhibition of histone deacetylase (HDAC) regulates DNA expression. HDAC inhibitors were identified in screening studies of compounds that could shift uveal melanoma cells from the class 2 to the class 1 signature. HDAC inhibitors have been shown to induce differentiation of uveal melanoma cells and dormancy of micrometastatic disease [45]. Thus, HDAC inhibitors may be well suited for adjuvant therapy applications, even though they may not be effective for advanced disease. HDAC inhibitors, including suberolanilide hydroxamic acid and valproic acid, are used clinically and are being considered for adjuvant testing in patients with high-risk uveal melanoma [44, 46].

\section{Hypomethylating Agents}

That alterations of epigenetic events by aberrant DNA methylation occur during melanoma progression is well established. DNA methylation is mediated by DNA methyltransferase. In melanoma models, frequent, intermittent, low concentrations of the DNA methyltransferase inhibitor decitabine suppressed proliferation and promoted cellular 
differentiation. This was associated with increases in the late differentiation genes relative to microphthalmia-associated transcription factor, a lineage-specific factor associated with melanocyte commitment. Frequent, intermittent, low-dose decitabine also induced alterations in potential host regulators of microphthalmia-associated transcription factor in the tumor stroma [47]. Host immune cells were also modified. Macrophage cytotoxicity and dendritic cell activation was increased and myeloid-derived suppressor cells were reduced [48]. An adjuvant trial of low-dose decitabine, which is in clinical use, in patients with highrisk uveal melanoma is being activated.

\section{Challenges in Designing Suitable Trials}

Uveal melanoma is a rare cancer. The sample sizes necessary to assess traditional clinical endpoints of adjuvant therapy are not practical. Novel trial designs are necessary [49]. That metastasis can be delayed also confounds trial development and interpretation. Molecular prognosis is still evolving. Tumor genotyping can identify patients at risk for metastasis and guide adjuvant therapy recommendations. Assessment of the primary tumor, however, does not indicate how far along the metastatic process is and cannot indicate whether treatment is reducing or eliminating metastasis. New blood biomarkers of uveal melanoma are needed. Finally, the biology of uveal and cutaneous melanoma is different, and extrapolations between the two are tenuous. The biology of micro- and macrometastatic melanoma is also different.

\section{Conclusion}

Adjuvant therapy has not been adequately studied in uveal melanoma. At present, there is no evidence that any approach improves outcome. Existing cytotoxic and immunotherapeutic regimens are now being more rationally applied using tumor genetic criteria to better identify patients at risk. Several novel cytotoxic, immunomodulatory, and targeted compounds are being investigated in the metastatic setting, alone and in combinations, which may be applicable to the adjuvant setting. Other immune checkpoint modulators are in development, such as those targeting the Program Death-1 pathway, and clinical testing of these are also anticipated. Other components of the MAPK pathway and other oncogenic pathways are also being targeted in uveal melanoma [50]. Approaches that promote uveal melanoma cellular differentiation and/or dormancy have shown promise in preclinical studies. Participation in welldesigned, scientifically sound clinical trials is essential to develop effective adjuvant therapies.

\section{References}

1 Damato B, Coupland SE: Translating uveal melanoma cytogenetics into clinical care. Arch Ophthalmol 2009; 127:423-429.

-2 Onken MD, Worley LA, Tuscan MD, Harbour JW: An accurate, clinically feasible multi-gene expression assay for predicting metastasis in uveal melanoma. J Mol Diagn 2010;12:461-468.

- 3 Kujala E, Makitie T, Kivela T: Very long-term prognosis of patients with malignant uveal melanoma. Invest Ophthalmol Vis Sci 2003;44:4651-4659.

4 Torres V, Triozzi P, Eng C, Tubbs R, Schoenfiled L, Crabb JW, Saunthararajah Y, Singh AD: Circulating tumor cells in uveal melanoma. Future Oncol 2011;7:101-109.

5 Desjardins L, Dorval T, Levy C, Cojean I, Schlienger P, Salmon RJ, Validire P, Asselain B: Etude randomisée de chimiothérapie adjuvante par le Déticène dans le mélanome choroïdien. Ophtalmologie 1998;12:168-173.

-6 McLean IW, Berd D, Mastrangelo MJ, Shields JA, Davidorf FH, Grever M, Makley TA, Gamel JW: A randomized study of methanol-extraction residue of bacille Calmette-Guerin as postsurgical adjuvant therapy of uveal melanoma. Am J Ophthalmol 1990;110:522-526. 
Ocular Oncology

and Pathology
Ocul Oncol Pathol 2015;1:54-62

DOI: $10.1159 / 000367715$

Triozzi and Singh: Adjuvant Therapy of Uveal Melanoma: Current Status

2014 S. Karger AG, Basel

www.karger.com/oop

7 Richtig E, Langmann G, Schlemmer G, Mullner K, Papaefthymiou G, Bergthaler P, Smolle: Verträglichkeit und Wirksamkeit einer adjuvanten Interferon-alfa-2b-Behandlung beim Aderhautmelanom. Ophthalmologe 2006;103:506-511.

-8 Lane AM, Egan KM, Harmon D, Holbrook A, Munzenrider JE, Gragoudas ES: Adjuvant interferon therapy for patients with uveal melanoma at high risk of metastasis. Ophthalmology 2009;116:2206-2212.

-9 Voelter V, Schalenbourg A, Pampallona S, Peters S, Halkic N, Denys A, Goitein G, Zografos L, Leyvraz S: Adjuvant intra-arterial hepatic fotemustine for high-risk uveal melanoma patients. Melanoma Res 2008;18:220-224.

10 Hodi FS, O’Day SJ, McDermott DF, Weber RW, Sosman JA, Haanen JB, Gonzalez R, Robert C, Schadendorf D, Hassel JC, Akerley W, van den Eertwegh AJ, Lutzky J, Lorigan P, Vaubel JM, Linette GP, Hogg D, Ottensmeier CH, Lebbé C, Peschel C, Quirt I, Clark JI, Wolchok JD, Weber JS, Tian J, Yellin MJ, Nichol GM, Hoos A, Urba WJ: Improved survival with ipilimumab in patients with metastatic melanoma. N Engl J Med 2010;363:711-723.

-11 Van Raamsdonk CD, Griewank KG, Crosby MB, Garrido MC, Vemula S, Wiesner T, Obenauf AC, Wackernagel W, Green G, Bouvier N, Sozen MM, Baimukanova G, Roy R, Heguy A, Dolgalev I, Khanin R, Busam K, Speicher MR, O’Brien J, Bastian BC: Mutations in GNA11 in uveal melanoma. N Engl J Med 2010;363:2191-2199.

12 Avril MF, Aamdal S, Grob JJ, Hauschild A, Mohr P, Bonerandi JJ, Weichenthal M, Neuber K, Bieber T, Gilde K, Guillem Porta V, Fra J, Bonneterre J, Saïag P, Kamanabrou D, Pehamberger H, Sufliarsky J, Gonzalez Larriba JL, Scherrer A, Menu Y: Fotemustine compared with dacarbazine in patients with disseminated malignant melanoma: a phase III study. J Clin Oncol 2004;22:1118-1125.

13 Becker JC, Terheyden P, Kämpgen E, Wagner S, Neumann C, Schadendorf D, Steinmann A, Wittenberg G, Lieb W, Bröcker EB: Treatment of disseminated ocular melanoma with sequential fotemustine, interferon alpha, and interleukin 2. Br J Cancer 2002;87:840-845.

14 Peters S, Voelter V, Zografos L, Pampallona S, Popescu R, Gillet M, Bosshard W, Fiorentini G, Lotem M, Weitzen R, Keilholz U, Humblet Y, Piperno-Neumann S, Stupp R, Leyvraz S: Intra-arterial hepatic fotemustine for the treatment of liver metastases from uveal melanoma: experience in 101 patients. Ann Oncol 2006;17:578-583.

15 Leyvraz S, Suciu S, Piperno-Neumann S, Baurain J-F, Zdzienicki M, Testori A, Marshall E, Scheulen ME, Jouary T, Negrier S, Vermorken JB, Kaempgen E, Durando X, Schadendorf D, Gurunath RK, Polders L, De Schaetzen G, Vanderschaeghe S, Gauthier MP, Keilholz U: Randomized phase III trial of intravenous (IV) versus hepatic intra-arterial (HIA) fotemustine in patients with liver metastases from uveal melanoma: final results of the EORTC 18021 study. J Clin Oncol 2012;30(suppl):abstr 8532.

16 EudraCT number: 2008-005691-27. https://www.clinicaltrialsregister.eu/ctr-search/search?query= eudract_number:2008-005691-27.

17 Güven K, Kittler H, Wolff K, Pehamberger H: Cisplatin and carboplatin combination as second-line chemotherapy in dacarbazine-resistant melanoma patients. Melanoma Res 2001;11:411-415.

18 Mahipal A, Tijani L, Chan K, Laudadio M, Mastrangelo MJ, Sato T: A pilot study of sunitinib malate in patients with metastatic uveal melanoma. Melanoma Res 2012;22:440-446.

19 Mac Neil S, Wagner M, Kirkham PR, Blankson EA, Lennard MS, Goodall T, Rennie IG: Inhibition of melanoma cell/matrix interaction by tamoxifen. Melanoma Res 1993;3:67-74.

20 Jones JA, Albright KD, Christen RD, Howell SB, McClay EF: Synergy between tamoxifen and cisplatin in human melanoma cells is dependent on the presence of antiestrogen-binding sites. Cancer Res 1997;57:2657-2660.

-21 Yoon YK, Im SA, Min A, Kim HP, Hur HS, Lee KH, Han SW, Song SH, Youn OD, Kim TY, Kim WH, Bang YJ: Sunitinib synergizes the antitumor effect of cisplatin via modulation of ERCC1 expression in models of gastric cancer. Cancer Lett 2012;321:128-136.

22 ClinicalTrials.gov identifier: NCT00489944. http://clinicaltrials.gov/show/NCT00489944.

-23 Stadler R, Luger T, Bieber T, Köhler U, Linse R, Technau K, Schubert R, Schroth K, Vakilzadeh F, Volkenandt M, Gollnick H, Von Eick H, Thoren F, Strannegård O: Long-term survival benefit after adjuvant treatment of cutaneous melanoma with dacarbazine and low dose natural interferon alpha: a controlled, randomised multicentre trial. Acta Oncol 2006;45:389-399.

-24 Yang H, Dithmar S, Grossniklaus HE: Interferon alpha 2b decreases hepatic micrometastasis in a murine model of ocular melanoma by activation of intrinsic hepatic natural killer cells. Invest Ophthalmol Vis Sci 2004;45: 2056-2064.

25 Wack C, Kirst A, Becker JC, Lutz WK, Bröcker EB, Fischer WH: Chemoimmunotherapy for melanoma with dacarbazine and 2,4-dinitrochlorobenzene elicits a specific $\mathrm{T}$ cell-dependent immune response. Cancer Immunol Immunother 2002;51:431-439.

-26 Konjević G, Jović V, Vuletić A, Radulović S, Jelić S, Spuzić I: CD69 on CD56+ NK cells and response to chemoimmunotherapy in metastatic melanoma. Eur J Clin Invest 2007;37:887-896.

-27 Hodi FS, O’Day SJ, McDermott DF, Weber RW, Sosman JA, Haanen JB, Gonzalez R, Robert C, Schadendorf D, Hassel JC, Akerley W, van den Eertwegh AJ, Lutzky J, Lorigan P, Vaubel JM, Linette GP, Hogg D, Ottensmeier CH, Lebbé C, Peschel C, Quirt I, Clark JI, Wolchok JD, Weber JS, Tian J, Yellin MJ, Nichol GM, Hoos A, Urba WJ: Improved survival with ipilimumab in patients with metastatic melanoma. N Engl J Med 2010;363:711-723.

28 Robert C, Thomas L, Bondarenko I, O’Day S, Weber J, Garbe C, Lebbe C, Baurain JF, Testori A, Grob JJ, Davidson N, Richards J, Maio M, Hauschild A, Miller WH Jr, Gascon P, Lotem M, Harmankaya K, Ibrahim R, Francis S, Chen TT, Humphrey R, Hoos A, Wolchok JD: Ipilimumab plus dacarbazine for previously untreated metastatic melanoma. N Engl J Med 2011;364:2517-2526. 
Ibrahim RA, Berman DM, DePril V, Humphrey RW, Chen T, Messina M, Chin KM, Liu HJ, Bielefield M, Hoos A: Ipilimumab safety profile: summary of findings from completed trials in advanced melanoma. J Clin Oncol 2011;29(suppl);abstr 8583.

-30 Kelderman S, van der Kooij MK, van den Eertwegh AJ, Soetekouw PM, Jansen RL, van den Brom RR, Hospers GA, Haanen JB, Kapiteijn E, Blank CU: Ipilimumab in pretreated metastastic uveal melanoma patients. Results of the Dutch Working Group on Immunotherapy of Oncology (WIN-O). Acta Oncol 2013;52:1786-1788.

-31 Maio M, Danielli R, Chiarion-Sileni V, Pigozzo J, Parmiani G, Ridolfi R, De Rosa F, Del Vecchio M, Di Guardo L, Queirolo P, Picasso V, Marchetti P, De Galitiis F, Mandalà M, Guida M, Simeone E, Ascierto PA: Efficacy and safety of ipilimumab in patients with pre-treated, uveal melanoma. Ann Oncol 2013;24:2911-2915.

32 Luke JJ, Callahan MK, Postow MA, Romano E, Ramaiya N, Bluth M, Giobbie-Hurder A, Lawrence DP, Ibrahim N, Ott PA, Flaherty KT, Sullivan RJ, Harding JJ, D’Angelo S, Dickson M, Schwartz GK, Chapman PB, Wolchok JD, Hodi FS, Carvajal RD: Clinical activity of ipilimumab for metastatic uveal melanoma: a retrospective review of the Dana-Farber Cancer Institute, Massachusetts General Hospital, Memorial Sloan-Kettering Cancer Center, and University Hospital of Lausanne experience. Cancer 2013;119:3687-3695.

33 Eggermont AM, Chiarion-Sileni V, Grob JJ, Dummer R, Wolchok JD, Schmidt H, Hamid O, Robert C, Ascierto PA Richards JM, Lebbe C, Ferraresi V, Smylie M, Weber JS, Maio M, Konto C, Gurunath RK, de Pril V, Suciu S, Testori A: Ipilimumab versus placebo after complete resection of stage III melanoma: initial efficacy and safety results from the EORTC 18071 phase III trial (abstract LBA9008). Program and Abstracts Am Soc Clin Oncol Annu Meet, Chicago, Ill, May 30 to June 3, 2014.

34 ClinicalTrials.gov identifier: NCT01585194. http://clinicaltrials.gov/show/NCT01585194.

35 Eubel J, Enk AH: Dendritic cell vaccination as a treatment modality for melanoma. Expert Rev Anticancer Ther 2009;9:1631-1642.

36 ClinicalTrials.gov identifier: NCT00929019. http://clinicaltrials.gov/show/NCT00929019.

Chapman PB, Hauschild A, Robert C, Haanen JB, Ascierto P, Larkin J, Dummer R, Garbe C, Testori A, Maio M, Hogg D, Lorigan P, Lebbe C, Jouary T, Schadendorf D, Ribas A, O’Day SJ, Sosman JA, Kirkwood JM, Eggermont AM, Dreno B, Nolop K, Li J, Nelson B, Hou J, Lee RJ, Flaherty KT, McArthur GA; BRIM-3 Study Group: Improved survival with vemurafenib in melanoma with BRAF V600E mutation. N Engl J Med 2011;364:2507-2516.

-38 Hauschild A, Grob JJ, Demidov LV, Jouary T, Gutzmer R, Millward M, Rutkowski P, Blank CU, Miller WH Jr, Kaempgen E, Martín-Algarra S, Karaszewska B, Mauch C, Chiarion-Sileni V, Martin AM, Swann S, Haney P, Mirakhur B, Guckert ME, Goodman V, Chapman PB: Dabrafenib in BRAF-mutated metastatic melanoma: a multicentre, open-label, phase 3 randomised controlled trial. Lancet 2012;380:358-365.

-39 Flaherty KT, Robert C, Hersey P, Nathan P, Garbe C, Milhem M, Demidov LV, Hassel JC, Rutkowski P, Mohr P, Dummer R, Trefzer U, Larkin JM, Utikal J, Dreno B, Nyakas M, Middleton MR, Becker JC, Casey M, Sherman LJ, Wu FS, Ouellet D, Martin AM, Patel K, Schadendorf D; METRIC Study Group: Improved survival with MEK inhibition in BRAF-mutated melanoma. N Engl J Med 2012;367:107-114.

-40 Flaherty KT, Infante JR, Daud A, Gonzalez R, Kefford RF, Sosman J, Hamid O, Schuchter L, Cebon J, Ibrahim N, Kudchadkar R, Burris HA 3rd, Falchook G, Algazi A, Lewis K, Long GV, Puzanov I, Lebowitz P, Singh A, Little S, Sun P, Allred A, Ouellet D, Kim KB, Patel K, Weber J: Combined BRAF and MEK inhibition in melanoma with BRAF V600 mutations. N Engl J Med 2012;367:1694-1703.

-41 Onken MD, Worley LA, Long MD, Duan S, Council ML, Bowcock AM, Harbour JW: Oncogenic mutations in GNAQ occur early in uveal melanoma. Invest Ophthalmol Vis Sci 2008;49:5230-5234.

42 Kirkwood JM, Bastholt L, Robert C, Sosman J, Larkin J, Hersey P, Middleton M, Cantarini M, Zazulina V, Kemsley $\mathrm{K}$, Dummer R: Phase II, open-label, randomized trial of the MEK1/2 inhibitor selumetinib as monotherapy versus temozolomide in patients with advanced melanoma. Clin Cancer Res 2012;18:555-567.

43 Carvajal RD, Sosman JA, Quevedo F, Milhem MM, Joshua AM, Kudchadkar RR, Linette GP, Gajewski T, Lutzky J, Lawson DH, Lao CD, Flynn PJ, Albertini MR, Sato T, Paucar D, Panageas KS, Dickson MA, Wolchok JD, Chapman PB, Schwartz GK: Phase II study of selumetinib (sel) versus temozolomide (TMZ) in gnaq/Gna11 (Gq/11) mutant (mut) uveal melanoma (UM). J Clin Oncol 2013;31(suppl):abstr CRA9003.

44 ClinicalTrials.gov identifier: NCT02068586. http://clinicaltrials.gov/show/NCT02068586. deacetylase inhibitors induce growth arrest and differentiation in uveal melanoma. Clin Cancer Res 2012;18: 408-416.

-46 Harbour JW: Genomic, prognostic, and cell-signaling advances in uveal melanoma. Am Soc Clin Oncol Educ Book 2013;2013:388-391.

$\$ 47$ Alcazar O, Achberger S, Aldrich W, Hu Z, Negrotto S, Saunthararajah Y, Triozzi P: Epigenetic regulation by decitabine of melanoma differentiation in vitro and in vivo. Int J Cancer 2012;131:18-29.

-48 Triozzi PL, Aldrich W, Achberger S, Ponnazhagan S, Alcazar O, Saunthararajah Y: Differential effects of low-dose decitabine on immune effector and suppressor responses in melanoma-bearing mice. Cancer Immunol Immunother 2012;61:1441-1450.

49 Whitehead J, Tishkovskaya S, O'Connor J, Damato B: Devising two-stage and multistage phase II studies on systemic adjuvant therapy for uveal melanoma. Invest Ophthalmol Vis Sci 2012;53:4986-3489.

50 Patel M, Smyth E, Chapman PB, Wolchok JD, Schwartz GK, Abramson DH, Carvajal RD: Therapeutic implications of the emerging molecular biology of uveal melanoma. Clin Cancer Res 2011;17:2087-2100. 